\title{
A centennial record of fluvial organic matter input from the discontinuous permafrost catchment of Lake Torneträsk
}

\author{
Jorien Vonk, Vanja Alling, Lars Rahm, Magnus Mörth, \\ Christoph Humborg and Örjan Gustafsson
}

\section{Linköping University Post Print}

N.B.: When citing this work, cite the original article.

An edited version of this paper was published by AGU.:

Jorien Vonk, Vanja Alling, Lars Rahm, Magnus Mörth, Christoph Humborg and Örjan Gustafsson, A centennial record of fluvial organic matter input from the discontinuous permafrost catchment of Lake Torneträsk, 2012, Journal of Geophysical Research, (117), G03018, 1-11.

http://dx.doi.org/10.1029/2011JG001887

Copyright 2012: American Geophysical Union (AGU)

http://sites.agu.org/

Postprint available at: Linköping University Electronic Press

http://urn.kb.se/resolve?urn=urn:nbn:se:liu:diva-79924 


\title{
A centennial record of fluvial organic matter input from the discontinuous permafrost catchment of Lake Torneträsk
}

\author{
Jorien E. Vonk, ${ }^{1,2}$ Vanja Alling, ${ }^{1}$ Lars Rahm,${ }^{3}$ Carl-Magnus Mörth, ${ }^{4,5}$ Christoph Humborg,, 5 \\ and Örjan Gustafsson ${ }^{1}$
}

Received 11 October 2011; revised 11 May 2012; accepted 23 June 2012; published 9 August 2012.

[1] High-latitude regions are underlain by the most organic carbon (OC)-rich soils on earth and currently subject to intense climate warming, potentially increasing remobilization and mineralization of soil OC. Sub-Arctic Scandinavia is located on the $0^{\circ} \mathrm{C}$ mean annual isotherm and is therefore particularly vulnerable to climate change. This study aimed to establish a baseline for soil OC release over the past century into Lake Torneträsk, the largest lake in sub-Arctic Scandinavia, through bulk geochemical and molecular radiocarbon analyses in chronologically constrained sediment cores. Our results suggest a dominance of peat-derived terrestrial OC inflow. We show that the annual terrestrial OC inflow to the lake is $\sim 12$ times higher than the in-lake produced particulate OC, and consists for a large part (ca. 60\%) of old OC from deep reservoirs in the catchment. The sedimentary record shows signs of increasing inflow of more degraded terrestrial matter since $\sim 1975$, as indicated by increasing \%TOC concentrations, a lower $\delta^{13} \mathrm{C}$ value and lower TOC:TN ratios. Based on simultaneous changes in local climate and reported signs of permafrost degradation (e.g., active layer deepening, mire/peat erosion), the observed changes in the sedimentary record of Scandinavia's largest mountain lake likely reflect a climate warming-induced change in terrestrial OC inflow.

Citation: Vonk, J. E., V. Alling, L. Rahm, C.-M. Mörth, C. Humborg, and Ö. Gustafsson (2012), A centennial record of fluvial organic matter input from the discontinuous permafrost catchment of Lake Torneträsk, J. Geophys. Res., 117, G03018, doi:10.1029/2011JG001887.

\section{Introduction}

[2] Inland waters are responsible for the transport, mineralization and storage of ca. 2.9 Pg C/yr [Tranvik et al., 2009] while their areal extent only corresponds to less than $2 \%$ of the ocean surface area [Dean and Gorham, 1998; Cole et al., 2007]. The northern boreal to sub-Arctic region is particularly rich in lakes and wetlands ( $7 \%$ and $21 \%$ of total land area, respectively) [Kortelainen et al., 2004] and plays an important role in terrestrial organic matter processing and regulating $\mathrm{OC}$ export to the nearby ocean [e.g., Algesten et al., 2004]. This region together with the entire northern

\footnotetext{
${ }^{1}$ Department of Applied Environmental Science (ITM) and the Bert Bolin Centre for Climate Research, Stockholm University, Stockholm, Sweden.

${ }^{2}$ Now at Geological Institute, ETH Zurich, Zurich, Switzerland.

${ }^{3}$ Department of Water and Environmental Studies, Linköping University, Linköping, Sweden.

${ }^{4}$ Department of Geological Sciences and the Bert Bolin Centre for Climate Research, Stockholm University, Stockholm, Sweden.

${ }^{5}$ Baltic Nest Institute, Stockholm University, Stockholm, Sweden.

Corresponding author: Ö. Gustafsson, Department of Applied Environmental Science, Stockholm University, S-10691 Stockholm, Sweden. (orjan.gustafsson@itm.su.se)

(C)2012. American Geophysical Union. All Rights Reserved. 0148-0227/12/2011JG001887
}

permafrost zone holds about half of the global below-ground soil OC [Tarnocai et al., 2009]. Ongoing climate warming, particularly strong at high northern latitudes [e.g., RichterMenge and Overland, 2010] may remobilize parts of the frozen OC pools into the contemporary carbon cycle. Schneider and Hook [2010] recently showed that inland water bodies are warming globally, since 1985, with the largest and most consistent warming trends occurring in northern Europe.

[3] Northern Scandinavia is a particularly vulnerable region because it is situated in the sub-Arctic with a mean annual air temperature near $0^{\circ} \mathrm{C}$, where permafrost is especially vulnerable [Johansson et al., 2006a]. Here, a small temperature shift can cause the frozen ground to thaw. A study in the Swedish sub-Arctic [Callaghan et al., 2010], based on a unique long-term time series on climate, cryosphere and ecology, shows that the threshold annual mean temperature of $0^{\circ} \mathrm{C}$ has already been crossed. This has led to multiple environmental impacts such as increases in active layer thickness [Äkerman and Johansson, 2008; Lyon et al., 2009], increases in snow thickness [Kohler et al., 2006], loss of lake ice cover [Callaghan et al., 2010], and increases in streamflow [Wilson et al., 2010]. Thawing permafrost has led to recent increases in lake water total OC (TOC) in small lakes [e.g., Rosén et al., 2009; Kokfelt et al., 2009], changes 
in vegetation [Johansson et al., 2006b; Malmer et al., 2005] and increases in mire erosion [Malmer et al., 2005]. The Abisko Scientific Research Station, responsible for these long-term time series, is located on the shore of Lake Torneträsk, the largest mountain lake in Scandinavia. Despite its climate-sensitive location and the well-studied surroundings (several hundred published papers, see http://www.polar.se/ en/node/371), there is not a single peer-reviewed paper published with focus on Lake Torneträsk. There are only a few reports by the local county [Länsstyrelsen Norrbottens Län, 1975, 2007] and one paper on the Abiskojokka delta [Andrén et al., 2002]. This study aims to characterize OC delivery to Lake Torneträsk in the last century, by analyzing two sediment cores from the deepest part of the lake. Radiochronological constraints, bulk geochemical (\%TOC, $\%$ total nitrogen $(\mathrm{TN}), \delta^{13} \mathrm{C}$ ) and mineralogical analyses (grain size) are combined with detailed molecular terrestrial biomarker analyses to reveal information on sources and degradation of the organic matter. Furthermore, we apply natural abundance radiocarbon measurements on both bulk sediment OC and molecular markers of recalcitrant soil carbon to shed light on the age and origin of OC from the climate-dynamic Torneträsk catchment.

\section{Methods}

\subsection{Study Area and Sampling Program}

[4] Lake Torneträsk was formed by glacial erosion and is the second-deepest lake in Sweden, with an estimated average depth of 50-58 m and maximum depth around $169 \mathrm{~m}$ [Mortimer and Mackereth, 1958]. The lake is about $80 \mathrm{~km}$ long and maximally $10 \mathrm{~km}$ wide and, unlike many other mountain lakes in the region, is not regulated for hydroelectric power. Water residence times are estimated to be 4-7 years. The duration of ice cover has decreased by around 40 days in the course of the last century [Callaghan et al., 2010] and currently lasts from early January to late May. Low summer water temperatures $\left(8^{\circ}\right.$ to $\left.9^{\circ} \mathrm{C}\right)$ due to the lake volume, long ice cover and wind exposure in combination with nutrient limitation [Bohman, 2003], cause a relatively low autochthonous productivity.

[5] The total catchment area of Lake Torneträsk covers ca. $3290 \mathrm{~km}^{2}$. On lower altitudes, boreal (birch) forests and mires dominate, with occasional pine forests. Tundra vegetation such as heath, dwarf birch and other shrubs occupy the mid-altitudes, whereas the higher altitudes are sparse in vegetation or snow covered. The region has been relatively undisturbed until the construction of a railroad "Malmbanan," built between 1898 and 1900 [Barck, 1996], and the construction of a parallel road in the early 1980s.

[6] Total river inflow is estimated to be from 1.4 to $2.0 \mathrm{~km}^{3} \mathrm{yr}^{-1}$ but total OC loadings are only known for a few rivers and streams (Table S1 in Text S1 in the auxiliary materials). ${ }^{1}$ The smaller lakes in the catchment trap much of the particulate OC flux before it reaches Lake Torneträsk. The sediments in Torneträsk are therefore likely to originate from fluvial input that has bypassed the small lakes such as glacio-fluvial material from mountain terraces and bank/rock erosion [Andrén et al., 2002]. Sparse TOC measurements in

\footnotetext{
${ }^{1}$ Auxiliary materials are available in the HTML. doi:10.1029/ 2011JG001887.
}

the lake show concentrations mostly in the range between 0.6 and $1.7 \mathrm{mg} \mathrm{L}^{-1}$ (see http://infol.ma.slu.se/ri/www_ri. acgi\$Project?ID=Intro) [Länsstyrelsen Norrbottens Län, 2007]. Surface sediment OC contents increase with lake depth [Länsstyrelsen Norrbottens Län, 1975], a clear sign that the deeper parts of the lake act as accumulation bottoms.

[7] The Abisko Scientific Research Station has monitored the local climate since 1913. At the station, mean annual temperatures have typically been below $0^{\circ} \mathrm{C}$ (longterm average of $-0.6^{\circ} \mathrm{C}$ between 1913 and 2006) but have risen above $0^{\circ} \mathrm{C}$ in recent years [Callaghan et al., 2010]. There is a strong $\mathrm{W}$-E climate gradient in the Torneträsk drainage basin, with a maritime, wet climate in the west ( $~ 900 \mathrm{~mm} \mathrm{yr}^{-1}$ near the Norwegian border) and drier continental climatic conditions toward the east, where Abisko stands out as a precipitation shadow $\left(\sim 300 \mathrm{~mm} \mathrm{yr}^{-1}\right)$. Permafrost occurs above ca. $880 \mathrm{~m}$ above sea level [Jeckel, 1988] and at lower elevations below mires and windexposed ridges [Johansson et al., 2006a]. The W-E climatic gradient is also reflected in the permafrost thickness $(\sim 2 \mathrm{~m}$ at the Norwegian border to $\sim 15 \mathrm{~m}$ along the eastern shores of Torneträsk).

[8] Sampling was conducted from the ice on the 3 and 4 May 2004, in one of the deep basins in the middle of Lake Torneträsk $\left(68.40^{\circ} \mathrm{N}, 18.82^{\circ} \mathrm{E}\right)$, ca. $5 \mathrm{~km}$ north of Abisko Scientific Research Station. Four cores (TT1-4) were taken within $10 \mathrm{~m}$ from eachother with an "Otto" gravity corer (constructed of PVC and Plexiglass liners at the Department of Geological Sciences, Stockholm University, Sweden) at $147 \mathrm{~m}$ lake depth. The core lengths were between 38 and $51 \mathrm{~cm}$. The sediment cores were sliced the same day in $1 \mathrm{~cm}$ slices, and stored frozen in petri dishes, pre-washed with $3 \mathrm{M} \mathrm{HNO}_{3}$ and extensive amounts of water, until further analyses.

\subsection{Dating}

[9] Excess ${ }^{210} \mathrm{~Pb}$ based radiochronology for the sediment core (TT2) was established using alpha spectrometry (Flett Research Ltd., Winnipeg, Canada). The resulting age-depth correlation, assuming a constant rate of supply model (CRS) [Appleby, 2001] is shown in Figure S1 in Text S1. The sediment distribution of the transient tracer ${ }^{137} \mathrm{Cs}$ was measured using a co-axial low energy spectrometer (EG\&G ORTEC) with a High-Purity Germanium detector. In this region, the ${ }^{137} \mathrm{Cs}$ signal corresponds to the 1986 Chernobyl peak rather than the global weapon testing signal (1960s) [e.g., Bigler and Hall, 2003; Algesten et al., 2006; Mattila et al., 2006]. At a depth of 16-18 cm, we measured a distinct offset in mineralogy, OC content and $\delta^{13} \mathrm{C}$ (see section 3.1) in combination with observations of abundant iron oxide particles. These irregularities most likely point toward the construction of the railroad along the entire southern shoreline (ca. $80 \mathrm{~km}$ ) of Lake Torneträsk between 1898 and 1900 [Barck, 1996]. The geochemically preserved signals of this well-known event thus constitute a useful transient tracer (much like ${ }^{137} \mathrm{Cs}$ ) which provides an agedepth reference point. The CRS-modeled ages in the deeper part of the core (gray symbols in Figure S1) are inconsistent with the known age-depth of the "railroad" layer (ca. 1900; $16-18 \mathrm{~cm})$. Since it is uncertain if background ${ }^{210} \mathrm{~Pb}$ was reached at the bottom of the core, this probably means that the sedimentation rates were slightly higher than the CRS- 
modeled ages. Therefore, we instead assumed a constant sedimentation rate (i.e., Constant Initial Concentration, CIC model) [Appleby, 2001] below $8 \mathrm{~cm}$ depth, which results in a ${ }^{210} \mathrm{~Pb}$ age-depth relationship that is consistent with the known age of the "railroad" layer.

[10] The two different cores that were collected were used for different analyses to meet all detection limits. Core TT1 was used for biomarker analyses and compound-specific radiocarbon analysis whereas core TT2 was used for ${ }^{210} \mathrm{~Pb}$, ${ }^{137} \mathrm{Cs}$, bulk TOC, $\delta^{13} \mathrm{C}-\mathrm{TOC}$, TN and grain size analyses. We find confirmation for parallel chronology in similar observations of deviations in section $16-18 \mathrm{~cm}$ in core TT2 (\%TOC, $\delta^{13} \mathrm{C}$, TOC:TN, mineralogy, iron oxide particles) and core TT1 (molecular proxies; see section 3.2, iron oxide particles), likely corresponding to the railroad construction.

\subsection{Grain Size, Bulk Elemental and Isotope Analyses}

[11] The grain size distribution in core TT2 was determined using a Micromeritics Sedigraph 5100 for mean and median grain size and percentage clays. The material had previously been sieved through a $63 \mu \mathrm{m}$ screen for determination of percentage sand in each sample.

[12] Analyses of carbon content and isotopic composition were executed with a Finnigan mass spectrometer (a Carlo Erba NC2500 elemental analyzer coupled to a Finnigan DeltaPlus Isotope Ratio Mass Spectrometer, Department of Geological Sciences, Stockholm University, using continuous flow). Before measurements, the material was freezedried, homogenized and carbonates were removed by $1 \mathrm{M}$ $\mathrm{HCl}$ addition to the samples. Based on standard measurements the errors in reported isotope signatures are $<0.2 \%$.

\subsection{Extraction and Isolation of Compounds}

[13] The freeze-dried and ground sediment slices were Soxhlet extracted $(24 \mathrm{~h})$ with dichloromethane/methanol $(\mathrm{DCM} / \mathrm{MeOH}, 2: 1 \mathrm{v} / \mathrm{v})$. Aliquots of the concentrated extracts were spiked with deuterated internal standards $\left(\mathrm{D}_{50^{-}}\right.$ tetracosane and $\mathrm{D}_{39}$-eicosanoic acid). The extracts were then separated into nonpolar and acid fractions with Bond-Elut ${ }^{\circledR}$ (bonded phase $\mathrm{NH}_{2}$, Varian, The Netherlands) and $\mathrm{Al}_{2} \mathrm{O}_{3}$ (100\% activated, Sigma-Aldrich) column chromatography. The $n$-alkanoic acids were derivatized to $n$-alkanoic methyl esters as described in Vonk et al. [2008]. Laboratory blanks revealed contamination of $\mathrm{C}_{16}$ and $\mathrm{C}_{18} n$-alkanoic acids, most likely originating from the Bond-Elut ${ }^{\circledR}$ columns [Russell and Werne, 2007]. No significant contamination occurred of any of the target analytes. Recoveries were on average $70 \pm 7.8 \%$ (one standard deviation; $\mathrm{n}=5$ ). We analyzed the nonpolar and acid fractions with gas chromatography - mass spectrometry (GC-MS) using an 8060 gas chromatograph interfaced to a MD 800 mass spectrometer (both Fisons PLC, Ipswich, Suffolk, UK) operating with electron ionization at $70 \mathrm{eV}$ and scanning from $\mathrm{m} / \mathrm{z} 50$ to 600 . The analytes were injected $(1 \mu \mathrm{l})$ on-column and separated on a PTE-5 (Supelco Inc, Bellefonte, Pennsylvania, USA) capillary column (5\%-diphenyl-dimethyl-polysiloxane, length $30 \mathrm{~m}$, i.d. $0.25 \mathrm{~mm}$, film thickness $0.25 \mu \mathrm{m}$ ). Temperature program settings can be found in Vonk et al. [2008].

\subsection{Radiocarbon Analyses}

[14] The long-chain $n$-alkanoic methyl esters were isolated from the purified extracts with preparative capillary GC
[Mandalakis and Gustafsson, 2003]. The system consisted of a HP 6890 Series II GC system equipped with a flame ionization detector and a 7683 Series injector from Agilent Technologies (Palo Alto, USA), connected to a cold injection system (CIS) and a Preparative Fraction Collector (PFC) from Gerstel GmbH (Mülheim an der Ruhr, Germany). The preparative capillary GC held a "megabore" fused silica capillary column ( $60 \mathrm{~m}$ length, $0.53 \mathrm{~mm}$ i.d.) coated with $0.5 \mu \mathrm{m}$ of VF-5MS (cross linked 5\% phenyl methylpolysiloxane, Factor Four, Varian) and used helium as carrier gas at a constant flow of $6.8 \mathrm{~mL} \mathrm{~min}{ }^{-1}$. The CIS injector was operated in "solvent vent" mode with a solvent venting time of $0.1 \mathrm{~min}$, and a splitless time of $2 \mathrm{~min}$. The GC oven temperatures for the $n$-alkanoic methyl esters were programmed from $70^{\circ} \mathrm{C}$ to $130^{\circ} \mathrm{C}$ with $20^{\circ} \mathrm{C} \mathrm{min}{ }^{-1}$, then to $300^{\circ} \mathrm{C}$ with $10^{\circ} \mathrm{C} \min ^{-1}$ where it was kept isothermally for $10 \mathrm{~min}$. Approximately $1 \%$ of the flow eluting from the capillary column was diverted to the FID while the other $99 \%$ was sent to the PFC. The PFC switch and transfer line temperatures were kept constant at $325^{\circ} \mathrm{C}$ through all injections. A sample volume of $5 \mu \mathrm{l}$ was repeatedly injected (between 20 and 45 runs) and the trapping times started ca. $0.5 \mathrm{~s}$ before and after the target compound eluted. Compound retention times were checked several times a day and the trapping windows were adjusted when necessary. The isolated compounds were run in full scan mode on GC-MS to determine purities ( $>99 \%$ for all fractions). To obtain sufficient amounts of carbon for ${ }^{14} \mathrm{C}$ analyses, the isolated $\mathrm{C}_{24}+\mathrm{C}_{26}+\mathrm{C}_{28}$ $n$-alkanoic methyl esters were recombined.

[15] The isolated fractions and bulk sediment samples were quantified at the U.S. National Ocean Sciences Accelerator Mass Spectrometry (NOSAMS) facility of the Woods Hole Oceanographic Institution (WHOI, Woods Hole, USA) for $\delta^{13} \mathrm{C}$ and $\Delta^{14} \mathrm{C}$ content [Pearson et al., 1998]. The solutions containing the isolated fractions were transferred into precombusted quartz tubes before precombusted copper oxide was added. The tubes were attached to a vacuum line, evacuated $\left(10^{-3}\right.$ Torr $)$ while immersed in isopropanol/dry ice slush $\left(-78^{\circ} \mathrm{C}\right)$, flame sealed, and combusted at $850^{\circ} \mathrm{C}$ for $5 \mathrm{~h}$. The resulting $\mathrm{CO}_{2}$ was introduced and purified on a vacuum line using a series of cold traps and quantified by manometry. About $10 \%$ of the $\mathrm{CO}_{2}$ was kept for $\delta^{13} \mathrm{C}$ analysis by isotope ratio mass spectrometry. The remaining fraction was reduced to graphite and targets of this graphite were mounted on target wheels for ${ }^{14} \mathrm{C}$ analysis by AMS. The ${ }^{14} \mathrm{C}$ results for $n$-alkanoic methyl esters were corrected for (i) time between sampling and sediment deposition and (ii) measured ${ }^{14} \mathrm{C}$ values of the methyl group from the derivatization agent $\left(\mathrm{BF}_{3}\right.$ in methanol) to obtain the inherent ${ }^{14} \mathrm{C}$ value for the $n$-alkanoic acids. All of the $\delta^{13} \mathrm{C}$ are reported relatively to the Vienna Pee Dee Belemnite (VPDB) standard, whereas radiocarbon results are reported relative to NBS oxalic acid I as $\Delta^{14} \mathrm{C}$ [Stuiver and Polach, 1997].

[16] The laboratories where processing of the samples took place were all tested with swab blank tests [Buchholz et al., 2000] to exclude trace background contamination from ${ }^{14} \mathrm{C}$-labeled compounds. Fortunately, all tests showed natural levels of ${ }^{14} \mathrm{C}$. Earlier tests with reference compounds (radiocarbon-dead PCB169 and modern vanillin) in our laboratory excluded contamination by non-fossil or fossil carbon sources, respectively [Zencak et al., 2007]. There is a 
small possibility that incomplete collection of the target molecules occurred during preparative GC processing, when trapping time windows did not cover the minor variations in elution times. However, this does not lead to significant isotopic fractionation and therefore does not bias the ${ }^{14} \mathrm{C}$ results [Zencak et al., 2007].

\section{Results and Discussion}

\subsection{Sedimentary Organic Carbon Characterization}

[17] The sedimentation rate over the last 100 years for Lake Torneträsk (average $1.6 \mathrm{~mm} \mathrm{yr}^{-1}$; Figure S1) is of a similar range as smaller lakes in the surroundings (from 0.6 to $2.4 \mathrm{~mm} \mathrm{yr}^{-1}$; Vuolep and Pajep Njakajaure, Inre Harrsjön) [Rosén et al., 2009; Kokfelt et al., 2009]. However, the $\% \mathrm{OC}$ is roughly an order of magnitude higher in the smaller lakes $(11 \%-28 \%)$ [Kokfelt et al., 2009] than in Lake Torneträsk $(1.0 \%-2.5 \%$; Figure $2 \mathrm{a})$. The OC content decreases down-core (Figure $2 \mathrm{a}$ ), whereas $\delta^{13} \mathrm{C}$ values vary between $-23 \%$ and $-25 \%$, with a trend toward higher values downcore (Figure 2b). Plankton communities in Torneträsk (pelagic $\delta^{13} \mathrm{C}$ values $-26.6 \%$ to $-30.2 \%$ [Bohman, 2003], and benthic values $-23.8 \%$ to $-24.9 \%$ ) overlap or lie close to commonly used terrestrial signatures $\left(\delta^{13} \mathrm{C}-27 \%\right.$ ). Source-apportionment of sediment OC into terrestrial versus autochthonous production by using $\delta^{13} \mathrm{C}$ is therefore challenging. Karlsson et al. [2002] surveyed 16 lakes in the vicinity of Lake Torneträsk and observed a similar, relatively enriched, signal in the sediment OC $(-23.9 \pm 2.3 \%$; mean \pm stdev) compared to the dissolved OC $(-28.5 \pm 0.70 \%$ o. They argued that benthic plankton/fauna contributes to this signal, which might also be the case for Lake Torneträsk. The TOC:TN ratios generally range between 11 and 13 (Figure 2d). Fresh terrestrial OC generally has high TOC:TN ratios (>20) [Meyers, 1994] and decreasing TOC:TN ratios with age [e.g., Kuhry and Vitt, 1996], while autochthonous material will behave opposite with a high initial TN content (in the form of amino acids) and a loss of $\mathrm{N}$ upon degradation [Dittmar et al., 2001]. Interpretation of the TOC:TN ratio can therefore be misleading when there are input of both terrestrial and autochthonous OC. Furthermore, the presence of inorganic $\mathrm{N}$ could lower the TOC:TN ratios.

[18] For the late 1890s, we observe an anomaly in the OC content and $\delta^{13} \mathrm{C}$ (Figures $2 \mathrm{a}$ and $2 \mathrm{~b}$ ). The construction of a railroad along the entire southern shoreline of Torneträsk, preceded by significant surficial land-clearing could explain the higher OC content and a lower, i.e., more terrestrial, $\delta^{13} \mathrm{C}$ signal. This horizon also shows a sudden increase in sand and clay content, in combination with decrease in silt (Figure 2c). Furthermore, the TOC:TN ratio is higher in this slice compared to the rest of the core (Figure $2 \mathrm{~d}$ ). The relatively high \%TOC, low $\delta^{13} \mathrm{C}$, and high TOC:TN are thus likely to reflect an inflow of relatively fresh (i.e., minimally degraded) terrestrial OM, as derived from land-clearing during the railroad construction, and imprinted in our core at 16-18 cm depth (ca. 1900).

[19] The core shows similar increases in \%TOC and decreases in the $\delta^{13} \mathrm{C}$ signal since around 1975 (Figures 2a and $2 b$ ), but a decrease in TOC:TN ratio (Figure $2 d$ ). This suggests an increase in terrestrial OM inflow since around 1975 (higher \%TOC, lower $\delta^{13} \mathrm{C}$ ), yet more degraded in character (lower TOC:TN). A shift in mineralogical properties, from ca. 1960 the \%clay decreases while the \%silt increases (Figure 2c), supports a shift in the source of sediment OC (i.e., containing more terrestrial OC) rather than a change in diagenetic processing in the top of the core. The possibility that the decrease in $\delta^{13} \mathrm{C}$ and TOC:TN is caused by an increasing autochthonous production due to a decrease in duration of ice-cover [Callaghan et al., 2010] is less plausible since most of the increase in ice-free period occurs in the dark winter, i.e., later freezeup, when autochthonous production is minimal. Besides, planktonic matter tends to degrade much faster than terrestrial matter [e.g., Hedges and Oades, 1997; Waite et al., 2005] so a strong autochthonous signal in the sediments seems unlikely. Instead, a relative increase in terrestrial OC inflow since $\sim 1975$ appears more plausible (see section 3.4).

\subsection{Source and Degradation State of Terrestrial Organic Matter}

[20] The sedimentary OC shows a clear molecular imprint of peatland vegetation. Molecular analyses showed an abundant presence of long-chain $n$-alkanes and $n$-alkanoic acids (350-950 $\mu \mathrm{g} \mathrm{g}^{-1}$ OC and 450-1700 $\mu \mathrm{g} \mathrm{g}^{-1} \mathrm{OC}$, respectively; individual concentrations in $\mu \mathrm{g} \mathrm{gdw}^{-1}$ are reported in Table S1). These compounds originate from epicuticular waxes in higher plants [Eglinton and Hamilton, 1967] and their resistance to degradation makes them eligible as proxies for recalcitrant soil organic matter [e.g., Smittenberg et al., 2006; Drenzek et al., 2007; van Dongen et al., 2008]. By using compounds specific to terrestrial sources, such as long-chain $n$-alkanes, we overcome mixing issues (i.e., autochthonous versus terrestrial) that may hinder the information value of bulk parameters such as OC content, $\delta^{13} \mathrm{C}$-TOC values or TOC:TN ratios. The long-chain $n$ alkane distribution can be used as a fingerprint for different kinds of terrestrial vegetation. Sub-Arctic Sphagnum mosses are dominated by the $\mathrm{C}_{25} n$-alkane homologue whereas higher plant leaf waxes contain more of the $\mathrm{C}_{29} n$-alkane homologue. The $n$-alkane proxy $\mathrm{C}_{25} /\left(\mathrm{C}_{25}+\mathrm{C}_{29}\right)$ [Vonk and Gustafsson, 2009] is therefore indicative of the contribution of Sphagnum (i.e., peatland) derived organic matter. Down-core in Lake Torneträsk, $\mathrm{C}_{25} /\left(\mathrm{C}_{25}+\mathrm{C}_{29}\right) n$-alkane ratios are between 0.46 and 0.69 (Figure $3 \mathrm{a}$ ). If one uses these ratios in a mixing model with a higher plant endmember of 0.07 and a Sphagnum end-member of 0.72 [Vonk and Gustafsson, 2009] this gives an $n$-alkane contribution from Sphagnum (i.e., peatland) between $60 \%$ and $70 \%$ with maxima around $80 \%-85 \%$ at recent depths and $96 \%$ in the late $1890 \mathrm{~s}$. The latter value can be explained by extensive surficial land-clearing and flushing into the lake during the construction of the Malmbanan railroad. The leaf wax distributions suggest that peatlands contribute relatively much to the terrestrial OC input, despite the limited distribution of mires in the Torneträsk catchment area $(\sim 5 \%-10 \%$ of the vegetated area; Figure 1). This can be explained by the relatively high $\mathrm{OC}$ content of peatland (global average $\sim 66.6 \mathrm{kgC} \mathrm{m} \mathrm{m}^{-2}$; regional estimate $20-50 \mathrm{kgC} \mathrm{m}^{-2}$ ) [Tarnocai et al., 2009; Malmer et al., 2005] compared to boreal forest soils $\left(\sim 9 \mathrm{kgC} \mathrm{m}^{-2}\right)$ [Jobbágy and Jackson, 2000]. In addition, the open boreal forests in the Torneträsk region contain quite some moss vegetation in the understory, contributing to the Sphagnum signal. 


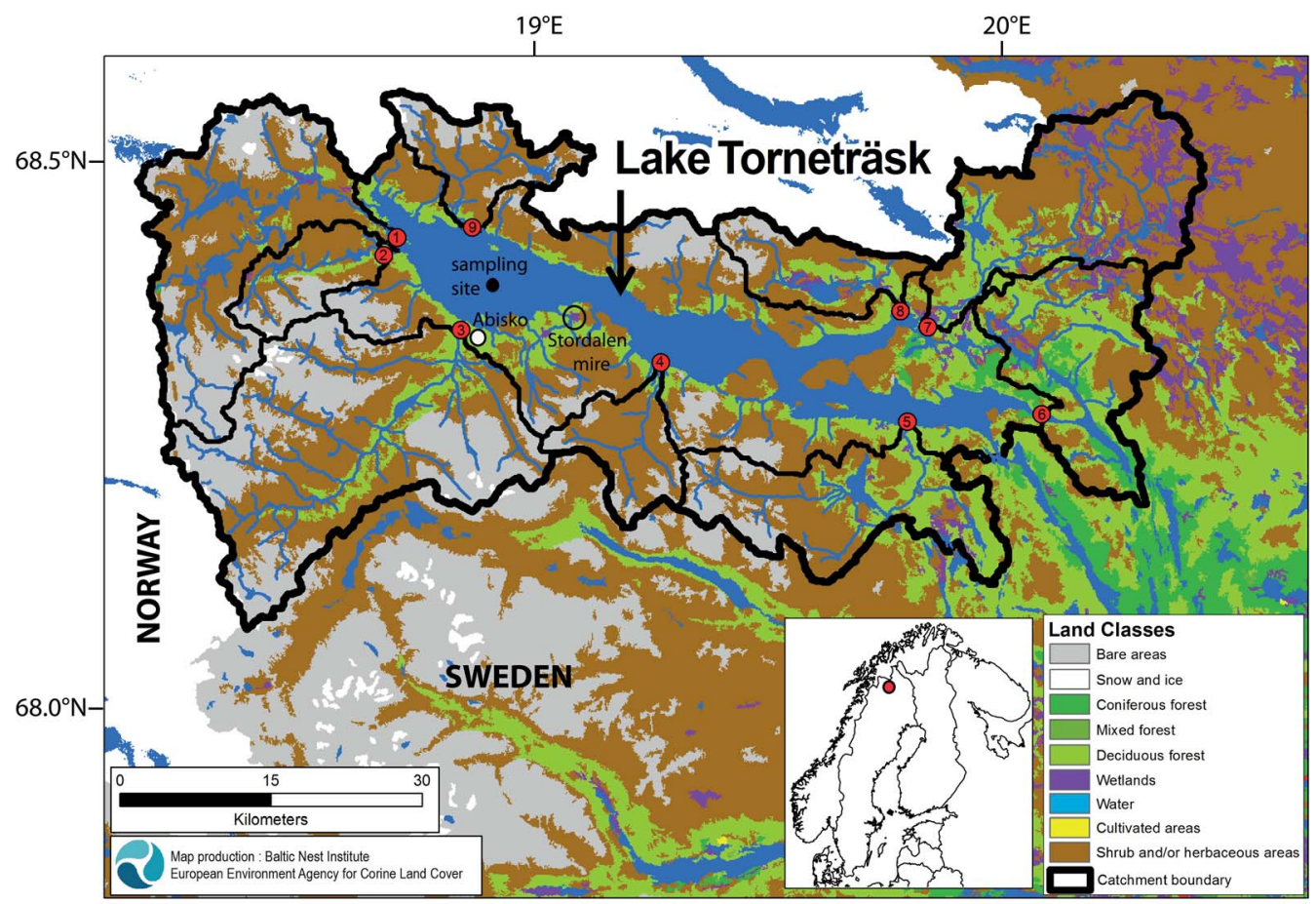

Figure 1. Location of Lake Torneträsk, the sediment core sampling location (black circle) and major inflows (red circles): (1) Njuoraätno, (2) Pahtajokka, (3) Abiskojokka, (4) Pessisjokka, (5) Nakeriätno, (6) Taalujokka, (7) Rakkisätno, (8) Ripasisjokka, (9) Snurijokka. More inflow information can be found in Table S1 in the auxiliary materials. The catchment boundary of Lake Torneträsk and inflowing rivers are shown in black.

[21] The ratio of long-chain $n$-alkanoic acids over $n$ alkanes (Figure $3 \mathrm{~b}$ ) is a tracer of the relative extent of degradation of terrestrial organic matter [e.g., van Dongen et al., 2008]. Here we observe a slight decrease of the ratio downcore corresponding to ongoing diagenesis, confirming the pattern observed in the bulk parameters. Also here, the sediment deposited during/after the railroad construction $(\sim 1898)$ is a distinct outlier. It exhibits a high ratio (i.e., minor degradation) that can be explained by a large inflow of surface soil OC and fresh vegetation caused by the landclearing. The odd-over-even predominance in long-chain $n$-alkanes and even-over-odd predominance in long-chain $n$-alkanoic acids, expressed as the carbon preference index (CPI; Figure 3c), is also an indicator of degradation status. Living plants typically have CPIs above 5 [Rielley et al., 1991] and the CPI decreases upon degradation. Here, the $n$-alkanoic acid CPIs are all lower than the $n$-alkane CPIs indicating that the former compounds are in a further degradation stage. Taken together, the terrestrial molecular analyses showed clear traces of OC input from Sphagnum or peatland vegetation, with signs of ongoing degradation.

[22] Opposite to bulk geochemical parameters (Figure 2), there are no clear trends in molecular proxies since $\sim 1975$ (Figures $3 \mathrm{~b}$ and 3c), except from a slight increase in the $\mathrm{C}_{25}$ / $\left(\mathrm{C}_{25}+\mathrm{C}_{29}\right)$ ratio (Figure 3a) tracing Sphagnum-derived terrestrial OC [Vonk and Gustafsson, 2009] and therefore an indication of increasing peat inflow. Unfortunately, the sediment core that was used for molecular analyses (core TT1) was sectioned with a coarser resolution than the other core (core TT2; used for bulk analyses) and also lacked a radiochronologically defined age-depth correlation. Trends are therefore less evident and harder to interpret.

\subsection{Age of Sedimentary Organic Matter}

[23] Radiocarbon measurements show that over the last century, old refractory OC from the watershed has significantly contributed to the total $\mathrm{OC}$ in Torneträsk lake sediments. Bulk sedimentary OC showed radiocarbon $\Delta^{14} \mathrm{C}$ signals between -360 and $-490 \%$, corresponding to 3600 to $5300{ }^{14} \mathrm{C}$ years of age (Table 1). A so-called "lake reservoir effect" could lower the true sedimentary OC age when the ${ }^{14} \mathrm{C}$ content of the carbon of which organisms built up their tissue is lower than the contemporaneous atmosphere [Björck and Wohlfarth, 2001]. These errors could be significant in extreme environments such as perennially icecovered lakes, sealed off from the atmosphere [e.g., Doran et al., 1999], or lakes that receive significant inflow from old groundwater or glacial water. In less-extreme environments such as our study region, this effect is usually very small.

[24] The true age of sedimentary OC can also be altered by a "hard-water reservoir effect" [Björck and Wohlfarth, 2001] when a lake receives inflow from calcareous rocks that produce ${ }^{14} \mathrm{C}$-dead inorganic carbon taken up by local plankton or aquatic communities [e.g., MacDonald et al., 1991]. Western Torneträsk receives inflow from limestone rocks, but the alkalinity is not very high $\left(0.27 \mathrm{meq} \mathrm{L}^{-1} ; \mathrm{pH}\right.$ 7.0 to 7.5) [Länsstyrelsen Norrbottens Län, 2007]. 

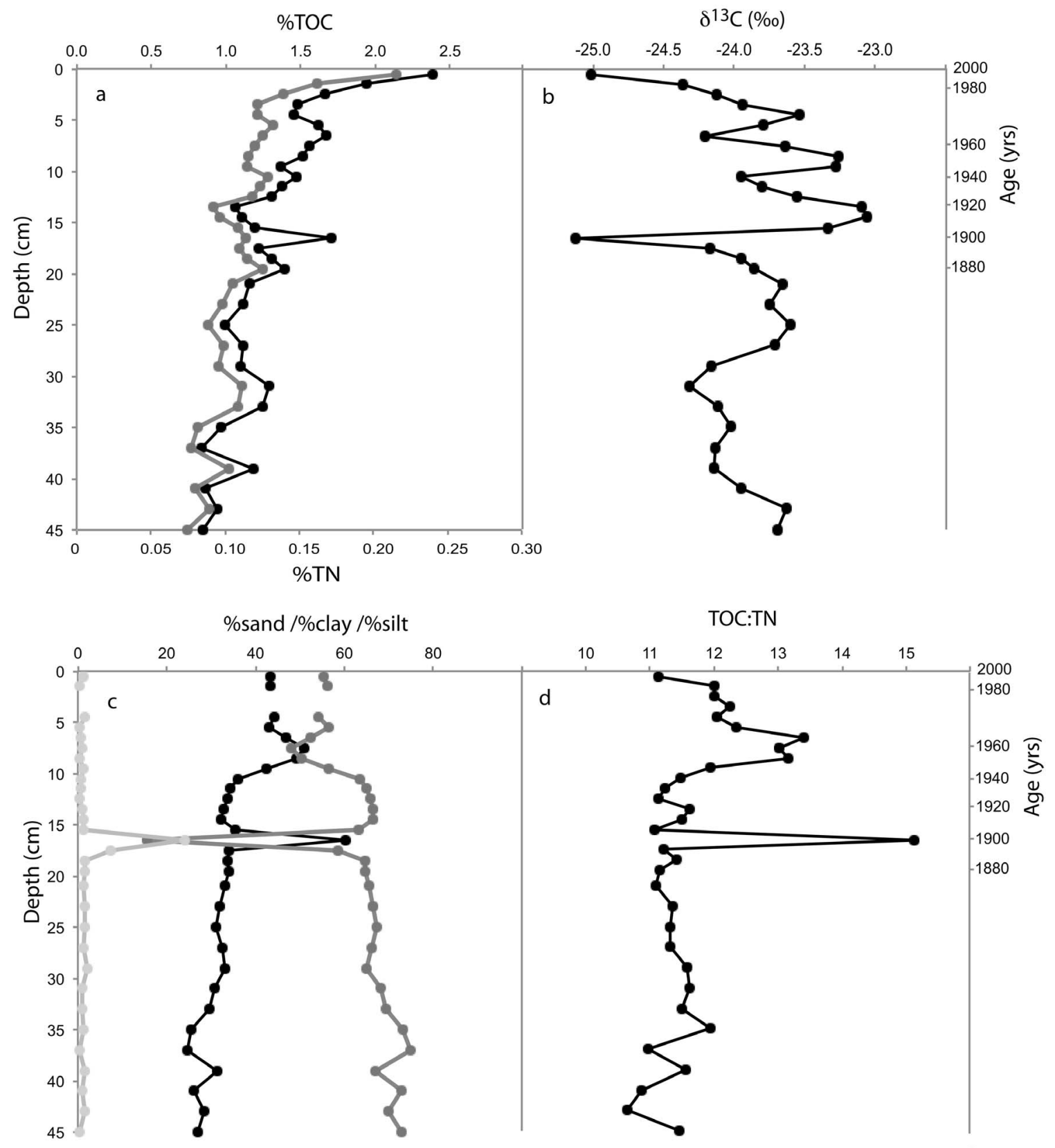

Figure 2. Bulk geochemical parameters in Lake Torneträsk sediment core (TT2) (radiochronologically constrained until 1880; see Figure S1 in Text S1): (a) \% total nitrogen (TN; gray) and \% total organic carbon (TOC; black); (b) $\delta^{13} \mathrm{C}(\%)$; (c) \% sand (light gray), \% clay (black) and \% silt (gray); and (d) atomic TOC:TN ratio.

[25] In order to compare the terrestrial OC inflow with the autochthonous signal and carbonates from weathering, we will make an estimate of the in-lake produced $\mathrm{C}$ utilizing nutrient and weathering ratios. Concentrations of $\mathrm{P}$ in Lake Torneträsk are close to the detection limit but a weak decrease $\left(1-2 \mu \mathrm{g} \mathrm{L}^{-1}\right)$ is usually observed above the (weak) summer thermocline suggesting a small production. Using an ordinary (molar) Redfield ratio of C:P 106:1, a P consumption of $1-2 \mu \mathrm{g} \mathrm{L}^{-1}$ would correspond with a $\mathrm{C}$ production of 140-280 tons $\mathrm{yr}^{-1}$, using a lake surface area of $332 \mathrm{~km}^{2}$ and $10 \mathrm{~m}$ water column depth. Here we do not consider water column mixing since deep lakes with an extensive ice cover are usually weakly stratified, as was shown for a similar large reservoir nearby [Sahlberg and Rahm, 2005]. In comparison, the input of $\mathrm{P}$ from rivers is probably around 5 ton/yr, assuming a mean specific $\mathrm{P}$ leakage in the catchment of $1.5 \mathrm{mg} \mathrm{P} \mathrm{m}^{-2}$ (based on data from Abiskojokka: $1.8 \mathrm{mg} \mathrm{P}$ $\mathrm{m}^{-2}$, and Pessisjokka: $1.1 \mathrm{mg} \mathrm{P} \mathrm{m}^{-2}$; data from Miljöanalys, Uppsala) and a Torneträsk catchment area of $3290 \mathrm{~km}^{2}$. When all $\mathrm{P}$ is used, this could give a primary production of 220 ton $\mathrm{C} \mathrm{yr}^{-1}$, which compares well with the above 140-280 ton $\mathrm{C} \mathrm{yr}^{-1}$.

[26] The contribution of radiocarbon-dead $\mathrm{C}$ from carbonates to in-lake production can be estimated through 

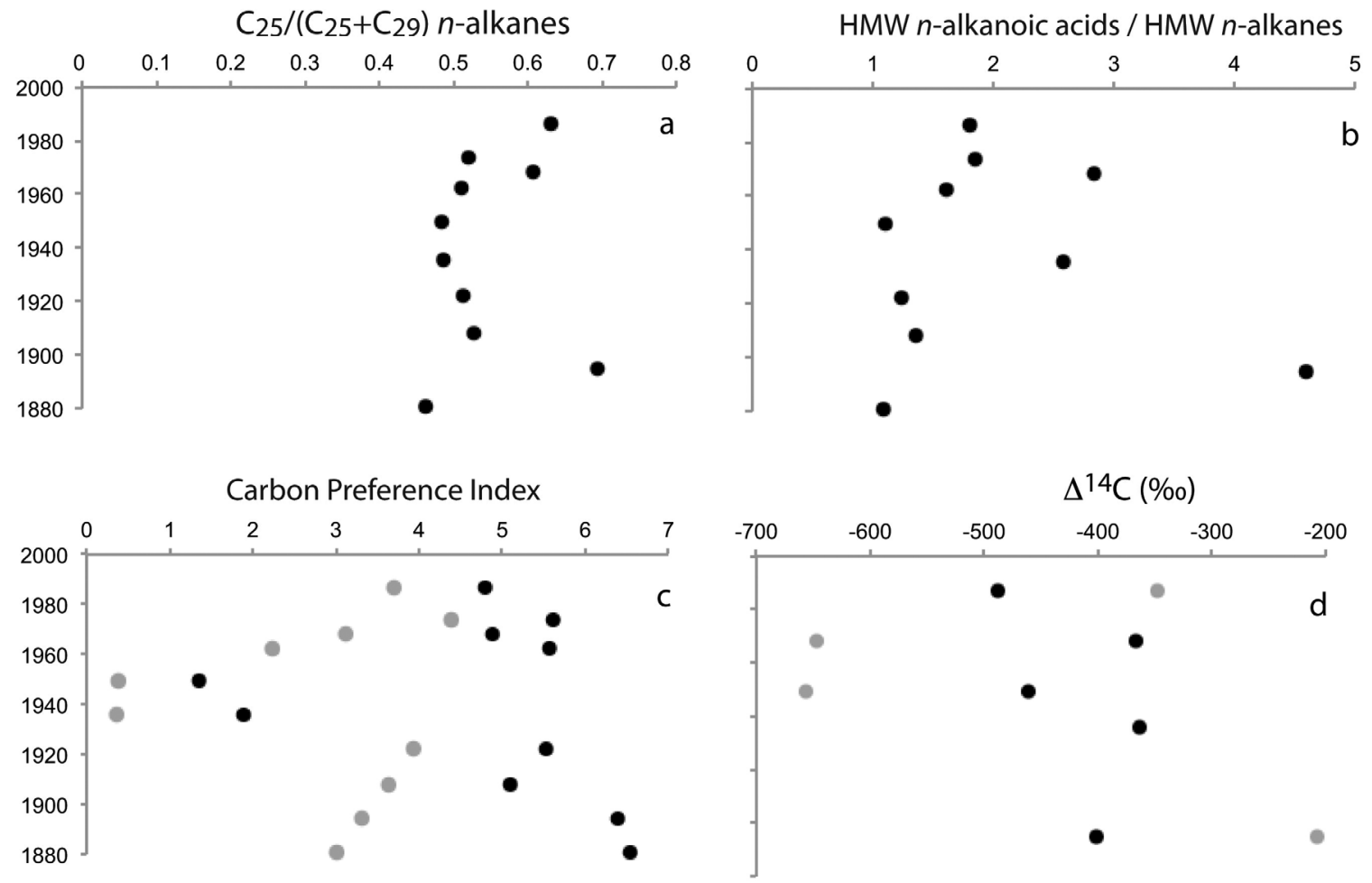

Figure 3. Molecular geochemical parameters in radiochronologically constrained Lake Torneträsk sediment core (TT1): (a) the ratio of $\mathrm{C}_{25}$ over $\left(\mathrm{C}_{25}+\mathrm{C}_{29}\right)$ long-chain $n$-alkanes as a proxy for Sphagnum (peatland) input; (b) the ratio of high-molecular weight (HMW) $n$-alkanoic acids over $n$-alkanes, indicative of degradation; (c) the Carbon Preference Index (CPI) for $n$-alkanoic acids $\left(\mathrm{C}_{20}-\mathrm{C}_{30}\right.$; gray) and $n$-alkanes $\left(\mathrm{C}_{21}-\mathrm{C}_{31}\right.$; black); and (d) radiocarbon content expressed as $\Delta^{14} \mathrm{C}(0 \%$ is contemporary; $-1000 \%$ is fossil) for bulk sediment OC (black) and high-molecular $n$-alkanoic acids $\left(\mathrm{C}_{24}+\mathrm{C}_{26}+\mathrm{C}_{28}\right.$; gray).

the $\mathrm{Ca} / \mathrm{Na}$ ratio, which is 3.0 in Lake Torneträsk (http://info1. ma.slu.se/ma/www_ma.acgi\$Station?ID=Intro\&S=2396) [Humborg et al., 2010]. If one assumes that the $\mathrm{Ca} / \mathrm{Na}$ ratio from silicate mineral weathering is 1.0 , the "excess" $\mathrm{Ca}(2.0)$ should originate from carbonate weathering:

$$
\mathrm{CaCO}_{3}(\mathrm{~s})+\mathrm{CO}_{2}(\mathrm{~g})+\mathrm{H}_{2} \mathrm{O} \rightarrow \mathrm{Ca}^{2}+(\mathrm{aq})+2 \mathrm{HCO}_{3}{ }^{-} \text {(aq) }
$$

Half of the $\mathrm{C}$ in $\mathrm{HCO}_{3}^{-}$comes from calcium carbonate $\left(\mathrm{CaCO}_{3}\right)$ and half from $\mathrm{CO}_{2}$, assumingly from the atmosphere and/or from respiration of organic $\mathrm{C}$. This means that only one third of the total inorganic $\mathrm{C}$ produced by mineral weathering (silicates and carbonates) comes from radiocarbon-dead $\mathrm{C}$. If we assume this ratio to be representative for the uptake of inorganic $\mathrm{C}$ by plankton, 70 ton out of ca. 210

Table 1. Carbon Isotope Composition and Age of Bulk Sediment OC and High-Molecular $n$-Alkanoic Acids $\left(\mathrm{C}_{24}+\mathrm{C}_{26}+\mathrm{C}_{28}\right)$ in the Torneträsk Core TT1

\begin{tabular}{lccccrrr}
\hline Depth $(\mathrm{cm})$ & Sample Size $(\mathrm{mg})$ & $\delta^{13} \mathrm{C}^{\mathrm{a}}(\%)$ & $\Delta^{14} \mathrm{C}^{\mathrm{b}}(\%)$ & $\mathrm{Fm}^{\mathrm{c}}$ & Error & ${ }^{14} \mathrm{C}$ Age & Error \\
\hline & & & Bulk OC & & & \\
$0-2$ & 4.3 & -24.8 & -488 & 0.515 & 0.006 & 5330 \\
$4-6$ & 15 & -23.7 & -367 & 0.637 & 0.002 & 3620 \\
$8-10$ & 24 & -23.9 & -462 & 0.542 & 0.002 & 4930 \\
$10-12$ & 180 & -23.9 & -364 & 0.640 & 0.002 & 3580 \\
$16-18$ & 23 & -24.7 & -401 & 0.603 & 0.001 & 4060 \\
& & & & & & 20 \\
$0-2$ & 0.030 & $-24.8^{\mathrm{d}}$ & n-Alkanoic Acids & & & \\
$4-6$ & 0.070 & -28.0 & -347 & 0.657 & 0.022 & 3370 \\
$8-10$ & 0.025 & -27.8 & -647 & 0.356 & 0.004 & 8300 \\
$16-18$ & 0.053 & -30.8 & -207 & 0.346 & 0.006 & 8510 \\
\end{tabular}

${ }^{a}$ Measured relative to Vienna Pee Dee Belemnite $(\mathrm{VPDB})$ and calculated according to: $\delta^{13} \mathrm{C}(\% \mathrm{~m})=\left(\mathrm{R}_{\mathrm{sample}} / \mathrm{R}_{\text {standard }}-1\right) * 1000$, where $\mathrm{R}$ is the ratio of ${ }^{13} \mathrm{C}$ to ${ }^{12} \mathrm{C}$.

${ }^{\mathrm{b}}$ Measured relative to NBS Oxalic Acid I and calculated according to: $\Delta^{14} \mathrm{C}(\% \mathrm{c})=\left(\mathrm{Fm} * \exp \left(\lambda^{*}[1950-\mathrm{Yc}]\right)-1\right]^{*} 1000$, where Fm is fraction modern, $\lambda$ is $1 /$ mean-life ${ }^{14} \mathrm{C}(1 / 8267)$ and $\mathrm{Yc}$ is year of collection (2005).

${ }^{\mathrm{c}} \mathrm{Fm}$ is $\delta^{13} \mathrm{C}$ corrected.

${ }^{\mathrm{d}}$ The sample volume was insufficient to measure $\delta^{13} \mathrm{C}$ for $\Delta^{14} \mathrm{C}$ correction. Instead, the Fm was corrected with $-24.8 \%$. 
ton (average of the 140-280 ton calculated above) in-lake produced $\mathrm{C}$ would be from radiocarbon-dead $\mathrm{C}$. Planktonic $\delta^{13} \mathrm{C}$ values of $-26.6 \%$ to $-30.2 \%$ [Bohman, 2003] support the minimal uptake of dissolved inorganic $\mathrm{C}$ from carbonates, which would lead to higher values (ca. $-20 \%$ ).

[27] The terrestrial inflow of OC is about 12 times higher with 2550 ton $\mathrm{C}$ (average annual inflow $1700 \times 10^{6} \mathrm{~m}^{3} \mathrm{yr}^{-1}$ times average TOC concentration of $1.5 \mathrm{mg} \mathrm{L}^{-1}$; see Table S2). We realize these TOC load calculations are not more than estimates, since TOC concentrations typically increase with discharge [e.g., Wheatcroft et al., 2010] and/or could be dominated by high-discharge events [e.g., Raymond and Saiers, 2010]. In any case, the maximum carbonate input would be around $2.5 \%(70 /(210+2550)$, which would make the true sedimentary $\mathrm{OC}{ }^{14} \mathrm{C}$ value $4 \%-10 \%$ more enriched, i.e., ca. $50-150$ years younger. This is clearly only a minor effect compared to bulk OC ages of $3600-5300{ }^{14} \mathrm{C}$ yrs. Note that a conservative assumption is made that similar preservation efficiencies into the sediments exist for all in-lake produced and terrestrial $\mathrm{OC}$.

[28] We argue that the old bulk sedimentary OC originates from inflow of old organic matter from the watershed [e.g., MacDonald et al., 1991; Abbott and Stafford, 1996]. This mechanism is confirmed by molecular radiocarbon analyses of long-chain $n$-alkanoic acids $\left(8300-8500{ }^{14} \mathrm{C}\right.$ yr; Table 1 ; Figure 3d), compounds exclusively occurring in higher plants. Similar ages have been measured on these higher plant markers in sediments of the nearby Bothnian Bay [Vonk et al., 2010], the bay that receives inflow from Torneträsk Lake and its catchment through the Torne River. The older ${ }^{14} \mathrm{C}$ age of the long-chain $n$-alkanoic acids compared to the bulk OC in the middle of the core, is likely reflecting either a contribution of autochthonous OC to the bulk OC and/or a longer turnover time for recalcitrant long-chain $n$-alkanoic acids than for bulk soil organic matter. For the core sections $0-2 \mathrm{~cm}$ and $16-18 \mathrm{~cm}$, the long-chain $n$-alkanoic acids are younger than the bulk OC. We reason this can be attributed to large-scale catchment disturbance, discussed further in this section.

[29] But why are the sedimentary OC and its terrestrial components several thousands years old? The southern parts of the Fennoscandian ice sheet started to retreat around 15,000 years ago, but did not leave the Torneträsk area icefree until around 9000 years ago [Donner, 1995]. We therefore hypothesize that there must be an additional input of early or pre-Holocene components. MacDonald et al. [2006] measured radiocarbon ages of basal peat in the circumArctic, including five points in the Torneträsk catchment. These locations had an average $\Delta^{14} \mathrm{C}$ signal of $-580 \%$ corresponding to 7800 calendar years before present. Groundwater base flow through this basal peat or through mineral soil layers from the same depth, could remobilize these old OC pools into the rivers and lake [Gustafsson et al., 2011]. Association with mineral particles protects the OC from extensive degradation during storage and transport [Vonk et al., 2010]. An additional early Holocene OC source could originate from old glaciofluvial deposits from the higher terraces in the valleys surrounding Lake Torneträsk [Andrén et al., 2002]. An even older pre-Holocene OC source could be delivered from pockets of relict $\mathrm{OC}$ in the catchment that have not been affected by glacial scouring during the last ice age. Fabel et al. [2002] showed that $20 \%-25 \%$ of the Torneträsk catchment consists of such relict surfaces.

[30] The younger age of the long-chain $n$-alkanoic acids in the top $(0-2 \mathrm{~cm})$ and bottom $(16-18 \mathrm{~cm})$ of the core $(140 \%$ and $190 \%$ more enriched in ${ }^{14} \mathrm{C}$ than bulk OC, respectively) could potentially be attributed to terrestrial $\mathrm{OC}$ inflow from land-clearing during construction of the railroad $(16-18 \mathrm{~cm}$; around 1900) and construction of the highway E10 (0-2 cm; early 1980s). The bulk of the flushed surficial OC is probably more easily degraded than the wax lipids (i.e., longchain $n$-alkanoic acids). In other words, the younger bulk OC is preferentially degraded and not visible in the sediments, whereas the long-chain $n$-alkanoic acids take longer time to degrade and leave their fingerprint in the sediments after burial. Additional reasons for the relatively young longchain $n$-alkanoic acid ${ }^{14} \mathrm{C}$ ages in the recent section $(0-2 \mathrm{~cm})$ could be an increase in rain storm events in recent decades [Callaghan et al., 2010; Jonasson and Nyberg, 1999] associated with significant slope and soil surface erosion and/or an input from thawing $\mathrm{OC}$ in the active layer, occurring in the complete Torneträsk region since around 1978 [Akerman and Johansson, 2008; Lyon et al., 2009] (see section 3.4).

[31] The relative input of old versus recent sources may be assessed with a simple isotopic mass balance equation for the bulk ${ }^{14} \mathrm{C}$ sediment OC samples. Assuming that the system has been in its natural state, i.e., without significant catchment disturbance, for the middle of the core, we take a mean ${ }^{14} \mathrm{C}$ value of bulk sediment $\mathrm{OC}$ of $-400 \%$ o $(n=3)$. If we reason that the old $\mathrm{OC}$ source is a mixture of $80 \%$ basal peat OC $(-580 \% ; \mathrm{n}=5)$ [MacDonald et al., 2006] and $20 \%$ [Fabel et al., 2002] relict OC $(-1000 \%)$, this gives an old OC $\Delta^{14} \mathrm{C}$ end-member of $-665 \%$. If we then apply a recent $\mathrm{OC}$ end-member value of $0 \%$, one would require a $60 \%$ contribution of old $\mathrm{OC}$ to give bulk $\mathrm{OC}{ }^{14} \mathrm{C}$ sample values around $-400 \%$. This is quite a significant contribution and demonstrates the important role of old and refractory OC in contemporary (sub)Arctic OC cycling. This adds to recent findings that a significant portion of fluvially released OC from the Eurasian Arctic originates in old carbon reservoirs [e.g., Guo et al., 2007; Vonk et al., 2010; Gustafsson et al., 2011].

\subsection{Signs of Climatic Change}

[32] Lake Torneträsk shows signs of increasing inflow of degraded terrestrial matter since approximately 1975, as indicated by increasing \% TOC concentrations, a lower $\delta^{13} \mathrm{C}$ value and lower TOC:TN ratios in the chronologically confined sediment core. Effects of climate warming in this region have been reported through numerous studies in the surrounding region, mostly in the valley south of Abisko and in Stordalen Mire (Figure 1). They observed a variable onset of climate warming impacts from the early 1970 to mid or late 1980s. Rosén et al. [2009] described larger fluctuations in lake-water TOC, pelagic-benthic ratios of primary producers and $\delta^{13} \mathrm{C}$ in sediments of Lake Vuolep Njakajaure, $4 \mathrm{~km}$ south of Abisko, since 1989 and attributed this to climate change and permafrost degradation in the catchment. Areal photographs of the Vuolep Njakajaure catchment showed a disappearance of large palsas between 1978 and 2000 , together with a decrease in birch forest and expansion of heath and mire vegetation [Rosén et al., 2009]. Annual 
temperature, precipitation, duration of ice-free conditions and snow depth all increased between 1959 and 2006 [Rosén et al., 2009; Kohler et al., 2006]. Callaghan et al. [2010] reports an ongoing warming from 1975, with acceleration from $\sim 2000$. Also, ground temperatures have been rising from 0.4 to $1^{\circ} \mathrm{C}$ between 1980 and 2002 [Johansson et al., 2011] which is corroborated by a regional increase in the active layer depth of more than $20 \mathrm{~cm}$ since the 1980s [Christensen et al., 2004]. A study in nearby Stordalen [Malmer et al., 2005] also made use of aerial photographs and plant population analysis to reveal a decrease in hummock vegetation and simultaneous increase in wet sites. They attributed this to permafrost degradation and higher spring temperatures. Furthermore, they calculated that a destruction of peat layers and mire erosion - in Stordalen mire only might have released 40-80 ton C during the period 19702000. Kokfelt et al. [2009] analyzed a sediment core from a small lake in this mire and observed an increase in lake-water TOC and lower $\delta^{13} \mathrm{C}$ values since the early 1980s. They attributed this to increased precipitation instead of permafrost decay, since the onset of the latter occurred later.

[33] We argue that it is likely that the changes observed in the sedimentary record since approximately 1975 can be attributed to changes in the local climate. An increased input of terrestrial OC from permafrost decay is one probable source. Alternatively, an increase in fluvial discharge and TOC load could also explain the increase in terrestrial input into Lake Torneträsk. This has however not been observed for Abiskojokka, one of the largest fluvial inflows and the only river draining into Torneträsk for which longer time series are available [Lyon et al., 2009]. Surface land-clearing, associated with the construction of highway E10 in the late 1980 s, is another potential source of additional terrestrial inflow to the lake, but this contribution probably was not significant. Instead, we argue that permafrost degradation, manifested through active layer deepening and mire/peat erosion, is a probable source of increasing terrestrial inflow into Torneträsk, or alternatively, is delivering terrestrial material that is less prone to degradation and shows a stronger imprint in the sediment.

[34] Future climate scenarios for the Abisko region predict an increase in air temperature by $4.5^{\circ} \mathrm{C}$ and an increase in precipitation by $18 \%$ (by 2080) [Saelthun and Barkved, 2003]. Further research is needed to monitor ongoing and future changes in this climate-sensitive region, and will allow for improved predictions on ecosystem responses to climate warming in the southern boundaries of the circumArctic permafrost region.

\section{Conclusions}

[35] Lake Torneträsk, in sub-Arctic Scandinavia, drains a large catchment that is located on the critical mean annual isotherm of $0^{\circ} \mathrm{C}$. It can therefore serve as a valuable model system to study (ongoing) impacts of a warming climate in the Arctic. This study uses a combination of bulk, molecular and isotopic geochemical analyses to show that the lake receives a terrestrial inflow of $\mathrm{OC}$ that is $\sim 12$ times larger than in-lake production. The terrestrial $\mathrm{OC}$ is characterized by peat-rich material and consists for a large part (ca. 60\%) of old OC from deep reservoirs in the catchment. The sedi- mentary record shows signs of increasing inflow of degraded terrestrial matter since $\sim 1975$ which could be attributed to an increase in climate warming-induced terrestrial OC release from permafrost thaw. When our findings are integrated over a larger scale, i.e., the southern boundaries of the circum-Arctic permafrost region currently hovering around the $0^{\circ} \mathrm{C}$ isotherm, this might suggest that these areas are already impacted by permafrost degradation.

[36] Acknowledgments. We thank personnel at the Abisko Scientific Research Station for helping out with transport to sampling locations and laboratory access, especially Bengt and Linnéa Wanhatalo, and Reiner Giesler. We also thank Heike Siegmund for $\delta^{13} \mathrm{C}$ measurements, Eve Arnold for assistance and access to equipment for grain size distribution measurements, Erik Smedberg for creating Figure 1, and Peter Rosén for valuable discussions. For financial support, we acknowledge the Swedish Research Council (VR contract numbers 621-2004-4039 and 629-20022309). J.E.V. and Ö.G. also acknowledge financial support as a Rubicon postdoctoral fellow through the Netherlands Organization for Scientific Research (NWO; grant \# 825.10.022) and as an Academy Research Fellow from the Swedish Royal Academy of Sciences through a grant from the Knut and Alice Wallenberg Foundation, respectively.

\section{References}

Abbott, M. B., and T. W. Stafford (1996), Radiocarbon geochemistry of modern and ancient Arctic lake systems, Baffin Island, Canada, Quat. Res., 45, 300-311, doi:10.1006/qres.1996.0031.

Åkerman, H. J., and M. Johansson (2008), Thawing permafrost and thicker active layers in sub-arctic Sweden, Permafrost Periglac. Processes, 19, 279-292, doi:10.1002/ppp.626.

Algesten, G., S. Sobek, A.-K. Bergström, A. Ågren, L. J. Tranvik, and M. Jansson (2004), Role of lakes for organic carbon cycling in the boreal zone, Global Change Biol., 10, 141-147, doi:10.1111/j.13652486.2003.00721.x.

Algesten, G. L., et al. (2006), Organic carbon budget for the Gulf of Bothnia, J. Mar. Syst., 63, 155-161, doi:10.1016/j.jmarsys.2006.06.004.

Andrén, H., C. Jonasson, and J. Ottosson (2002), The Abiskojokka delta in Lake Torneträsk, Geogr. Ann., Ser. A, 84, 151-156, doi:10.1111/j.04353676.2002.00169.x.

Appleby, P. G. (2001), Chronostratigraphic techniques in recent sediments, in Tracking Environmental Change Using Lake Sediments, vol. 1, edited by W. M. Last and J. P. Smol, pp. 171-203, Kluwer Acad., Dordrecht, Netherlands, doi:10.1007/0-306-47669-X 9.

Barck, Å. (1996), 104 år på Malmbanan: En historisk sammanfattning, Mediafolket, Statens Järnvägar.

Bigler, C., and R. I. Hall (2003), Diatoms as quantitative indicators of July temperature: A validation attempt at century-scale with meteorological data from northern Sweden, Palaeogeogr. Palaeoclimatol. Palaeoecol. 189, 147-160, doi:10.1016/S0031-0182(02)00638-7.

Björck, S., and B. Wohlfarth (2001), ${ }^{14} \mathrm{C}$ Chronostratigraphic techniques in paleolimnology, in Tracking Environmental Change Using Lake Sediments, vol. 1, edited by W. M. Last and J. P. Smol, pp. 205-245, Kluwer Acad., Dordrecht, Netherlands, doi:10.1007/0-306-47669-X_10.

Bohman, T. (2003), Stable isotope distribution in pelagic food webs in river headwaters of Swedish Lapland, MA thesis, Inst. for Syst. Ecol., Stockholm Univ., Stockholm.

Buchholz, B. A., S. P. H. T. Freeman, K. W. Haack, and J. S. Vogel (2000), Tips and traps in the ${ }^{14} \mathrm{C}$ bio-AMS preparation laboratory, $\mathrm{Nucl}$. Instrum. Methods Phys. Res., Sect. B, 172, 404-408, doi:10.1016/S0168-583X(00) 00142-7.

Callaghan, T. V., F. Bergholm, T. R. Christensen, C. Jonasson, U. Kokfelt, and M. Johansson (2010), A new climate era in the sub-Arctic: Accelerating climate changes and multiple impacts, Geophys. Res. Lett., 37, L14705, doi:10.1029/2009GL042064.

Christensen, T. R., T. Johansson, H. J. Åkerman, M. Mastepanov, N. Malmer, T. Friborg, P. Crill, and B. H. Svensson (2004), Thawing sub-arctic permafrost: Effects on vegetation ad methane submissions, Geophys. Res. Lett., 31, L04501, doi:10.1029/2003GL018680.

Cole, J. J., et al. (2007), Plumbing the global carbon cycle: Integrating inland waters into the terrestrial carbon budget, Ecosystems (N. Y.), 10, 172-185, doi:10.1007/s10021-006-9013-8.

Dean, W. E., and E. Gorham (1998), Magnitude and significance of carbon burial in lakes, reservoirs, and peatlands, Geology, 26, 535-538, doi:10.1130/0091-7613(1998)026<0535:MASOCB>2.3.CO;2. 
Dittmar, T., H. P. Fitznar, and G. Kattner (2001), Origin and biogeochemical cycling of organic nitrogen in the Eastern Arctic Ocean as evident from D- and L-amino acids, Geochim. Cosmochim. Acta, 65, 4103-4114, doi:10.1016/S0016-7037(01)00688-3.

Donner, J. (1995), The quaternary history of Scandinavia, Cambridge Univ. Press, Cambridge.

Doran, P. T., G. W. Berger, W. B. Lyons, R. A. Wharton, M. L. Davisson, J. Southon, and J. E. Dibb (1999), Dating Quaternary lacustrine sediments in the McMurdo Dry Valleys, Antarctica, Palaeogeogr. Palaeoclimatol. Palaeoecol., 147, 223-239, doi:10.1016/S0031-0182(98)00159-X.

Drenzek, N. J., D. B. Montluçon, M. B. Yunker, R. W. Macdonald, and T. I. Eglinton (2007), Constraints on the origin of sedimentary organic carbon in the Beaufort Sea from coupled molecular ${ }^{13} \mathrm{C}$ and ${ }^{14} \mathrm{C}$ measurements, Mar. Chem., 103, 146-162, doi:10.1016/j.marchem.2006.06.017.

Eglinton, G., and R. J. Hamilton (1967), Leaf epicuticular waxes, Science, 156, 1322-1335, doi:10.1126/science.156.3780.1322.

Fabel, D., A. P. Stroeven, J. Harbor, J. Kleman, D. Elmore, and D. Fink (2002), Landscape preservation under Fennoscandian ice sheets determined from in situ produced ${ }^{10} \mathrm{Be}$ and ${ }^{26} \mathrm{Al}$, Earth Planet. Sci. Lett. 201, 397-406, doi:10.1016/S0012-821X(02)00714-8.

Guo, L., C.-L. Ping, and R. W. MacDonald (2007), Mobilization pathways of organic carbon from permafrost to arctic rivers in a changing climate, Geophys. Res. Lett., 34, L13603, doi:10.1029/2007GL030689.

Gustafsson, Ö., B. E. van Dongen, J. E. Vonk, O. V. Dudarev, and I. P. Semiletov (2011), Widespread release of old carbon across the Siberian Arctic echoed by its large rivers, Biogeosciences, 8, 1737-1743, doi:10.5194/bg-8-1737-2011.

Hedges, J. I., and J. M. Oades (1997), Comparative organic geochemistries of soils and marine sediments, Org. Geochem., 27, 319-361, doi:10.1016/S0146-6380(97)00056-9.

Humborg, C., C.-M. Mörth, M. Sundbom, H. Borg, T. Blenckner, R. Giesler, and V. Ittekkot (2010), $\mathrm{CO}_{2}$ supersaturation along the aquatic conduit in Swedish watersheds as constrained by terrestrial respiration, aquatic respiration and weathering, Global Change Biol., 16 , 1966-1978, doi:10.1111/j.1365-2486.2009.02092.x.

Jeckel, P. P. (1988), Permafrost and its altitudinal zonation in N. Lapland, in Permafrost: Fifth International Conference, August 2-5, 1988, Vol. 1, edited by K. Senneset, pp. 170-175, Tapir, Trondheim, Norway.

Jobbágy, E. G., and R. B. Jackson (2000), The vertical distribution of soil organic carbon and its relation to climate and vegetation, Ecol. Appl., 10, 423-436, doi:10.1890/1051-0761(2000)010[0423:TVDOSO] 2.0.CO;2.

Johansson, M., T. R. Christensen, J. Åkerman, and T. V. Callaghan (2006a), What determines the current presence or absence of permafrost in the Torneträsk region, a sub-Arctic landscape in northern Sweden? Ambio, 35, 190-197, doi:10.1579/0044-7447(2006)35[190:WDTCPO] 2.0.CO;2.

Johansson, T., N. Malmer, P. M. Crill, T. Friborg, J. Åkerman, M Mastepanov, and T. Christensen (2006b), Decadal vegetation changes in a northern peatland, greenhouse gas fluxes and net radiative forcing, Global Change Biol., 12, 2352-2369, doi:10.1111/j.1365-2486.2006. 01267.x.

Johansson, M., J. Åkerman, F. Keuper, T. R. Christensen, H. Lantuit, and T. V. Callaghan (2011), Past and present permafrost temperatures in the Abisko area: Redrilling of boreholes, Ambio, 40, 558-565, doi:10.1007/ s13280-011-0163-3.

Jonasson, C., and R. Nyberg (1999), The rainstorm of August 1998 in the Abisko area, northern Sweden: Preliminary report on observations of erosion and sediment transport, Geogr. Ann., Ser A, 81, 387-390, doi:10.1111/j.0435-3676.1999.00068.x.

Karlsson, J., M. Jansson, and A. Jonsson (2002), Similar relationships between pelagic primary and bacterial production in clearwater and humic lakes, Ecology, 83, 2902-2910, doi:10.1890/0012-9658(2002) 083[2902:SRBPPA]2.0.CO;2.

Kohler, J., O. Brandt, M. Johansson, and T. Callaghan (2006), A long-term Arctic snow depth record from Abisko, northern Sweden, 1913-2004, Polar Res., 25, 91-113, doi:10.1111/j.1751-8369.2006.tb00026.x.

Kokfelt, U., et al. (2009), Ecosystem responses to increased precipitation and permafrost decay in subarctic Sweden inferred from peat and lake sediments, Global Change Biol., 15, 1652-1663, doi:10.1111/j.13652486.2009.01880.x

Kortelainen, P., H. Pajunen, M. Rantakari, and M. Saarnisto (2004), A large carbon pool and small sink in boreal lake Holocene sediments, Global Change Biol., 10, 1648-1653, doi:10.1111/j.1365-2486.2004.00848.x.

Kuhry, P., and D. H. Vitt (1996), Fossil carbon/nitrogen ratios as a measure of peat decomposition, Ecology, 77, 271-275, doi:10.2307/2265676.

Länsstyrelsen Norrbottens Län (1975), Naturvårdsenheten Torneträsk vatten- och sedimentkvalitet (in Swedish), Environ. Assess. Rep., North. Reg. Off., Luleå, Sweden.
Länsstyrelsen Norrbottens Län (2007), Regional miljöövervakning - Stora sjöar (in Swedish), Environ. Assess. Rep., North. Reg. Off., Luleå, Sweden.

Lyon, S. W., G. Destouni, R. Giesler, C. Humborg, M. Mörth, J. Seibert, J. Karlsson, and P. A. Troch (2009), Estimation of permafrost thawing rates in a sub-arctic catchment using recession flow analysis, Hydrol. Earth Syst. Sci., 13, 595-604, doi:10.5194/hess-13-595-2009.

MacDonald, G. M., R. P. Beukens, and W. E. Kieser (1991), Radiocarbon dating of limnic sediments: A comparative analysis and discussion, Ecology, 72, 1150-1155, doi:10.2307/1940612.

MacDonald, G. M., D. W. Beilman, K. V. Kremenetski, Y. Sheng, L. C. Smith, and A. A. Velichko (2006), Rapid early development of circumarctic peatlands and atmospheric $\mathrm{CH}_{4}$ and $\mathrm{CO}_{2}$ variations, Science, 314, 285-288, doi:10.1126/science. 1131722 .

Malmer, N., T. Johansson, M. Olsrud, and T. R. Christensen (2005), Vegetation, climatic changes and net carbon sequestration in a NorthScandinavian subarctic mire over 30 years, Global Change Biol., 11, 1895-1909, doi:10.1111/j.1365-2486.2005.01042.x.

Mandalakis, M., and Ö. Gustafsson (2003), Optimization of a preparative capillary gas chromatography-mass spectrometry system for the isolation and harvesting of individual polycyclic aromatic hydrocarbons, J. Chromatogr. A, 996, 163-172, doi:10.1016/S0021-9673(03)00612-5.

Mattila, J., H. Kankaanpää, and E. Ilus (2006), Estimation of recent sediment accumulation rates in the Baltic Sea using artificial radionuclides ${ }^{137} \mathrm{Cs}$ and ${ }^{239,240} \mathrm{Pu}$ as time markers, Boreal Environ. Res., 11, 95-107.

Meyers, P. A. (1994), Preservation of elemental and isotopic source identification of sedimentary organic matter, Chem. Geol., 114, 289-302, doi:10.1016/0009-2541(94)90059-0.

Mortimer, C. H., and F. J. H. Mackereth (1958), Convection and its consequences in ice-covered lakes, Verh. Internat. Ver. Limnol., XIII, 923-932. Pearson, A., A. P. McNichol, R. J. Schneider, and K. F. Von Reden (1998), Microscale AMS 14C measurement at NOSAMS, Radiocarbon, 40, 61-75.

Raymond, P., and J. Saiers (2010), Event controlled DOC export from forested watersheds, Biogeochemistry, 100, 197-209, doi:10.1007/ s10533-010-9416-7.

Richter-Menge, J., and J. E. Overland (Eds.) (2010), Arctic report card 2010, http://www.arctic.noaa.gov/reportcard, NOAA Arctic Res. Program, Washington, D. C

Rielley, G., R. J. Collier, D. M. Jones, and G. Eglinton (1991), The biogeochemistry of Ellesmere Lake, U.K.-I. Source correlation of leaf wax inputs to the sedimentary lipid record, Org. Geochem., 17, 901-912, doi:10.1016/0146-6380(91)90031-E.

Rosén, P., L. Cunningham, J. Vonk, and J. Karlsson (2009), Effects of climate on organic carbon and ratio of planktonic to benthic primary producers in a subarctic lake during the past 45 years, Limnol. Oceanogr., 54, 1723-1732, doi:10.4319/1o.2009.54.5.1723.

Russell, J. M., and J. P. Werne (2007), The use of solid phase extraction columns in fatty acid purification, Org. Geochem., 38, 48-51, doi:10.1016/j. orggeochem.2006.09.003

Saelthun, N. R., and L. Barkved (2003), Climate change scenarios for the SCANNET region, NIVA Rep. SNO 4663-2003, 74 pp., Norw. Inst. for Water Res., Oslo.

Sahlberg, J., and L. Rahm (2005), Light limitation of primary production in high latitude reservoirs, Hydrol. Earth Syst. Sci., 9, 707-720, doi:10.5194/hess-9-707-2005

Schneider, P., and S. J. Hook (2010), Space observations of inland water bodies show rapid surface warming since 1985, Geophys. Res. Lett., 37 L22405, doi:10.1029/2010GL045059.

Smittenberg, R. H., T. I. Eglinton, S. Schouten, and J. S. Sinninghe Damsté (2006), Ongoing buildup of refractory organic carbon in boreal soils during the Holocene, Science, 314, 1283-1286, doi:10.1126/science. 1129376

Stuiver, M., and H. A. Polach (1997), Discussion - Reporting of ${ }^{14} \mathrm{C}$ data, Radiocarbon, 19, 355-363.

Tarnocai, C., J. G. Canadell, E. A. G. Schuur, P. Kuhry, G. Mazhitova, and S. Zimov (2009), Soil organic carbon pools in the northern circumpolar permafrost region, Global Biogeochem. Cycles, 23, GB2023, doi:10.1029/2008GB003327.

Tranvik, L. J., et al. (2009), Lakes and reservoirs as regulators of carbon cycling and climate, Limnol. Oceanogr., 54, 2298-2314, doi:10.4319/ 10.2009.54.6 part 2.2298.

van Dongen, B. E., I. Semiletov, J. W. H. Weijers, and Ö. Gustafsson (2008), Contrasting lipid biomarker composition of terrestrial organic matter exported from across the Eurasian Arctic by the five great Russian Arctic rivers, Global Biogeochem. Cycles, 22, GB1011, doi:10.1029/ $2007 \mathrm{~GB} 002974$. 
Vonk, J. E., and Ö. Gustafsson (2009), Calibrating n-alkane Sphagnum proxies in sub-Arctic Scandinavia, Org. Geochem., 40, 1085-1090, doi:10.1016/j.orggeochem.2009.07.002.

Vonk, J. E., B. E. van Dongen, and Ö. Gustafsson (2008), Lipid biomarker investigation of the origin and diagenetic state of sub-arctic terrestrial organic matter presently exported into the northern Bothnian Bay, Mar. Chem., 112, 1-10, doi:10.1016/j.marchem.2008.07.001.

Vonk, J. E., B. E. van Dongen, and Ö. Gustafsson (2010), Selective preservation of old organic carbon fluvially released from sub-Arctic soils, Geophys. Res. Lett., 37, L11605, doi:10.1029/2010GL042909.

Waite, A. M., Ö. Gustafsson, O. Lindahl, and P. Tiselius (2005), Linking ecosystem dynamics and biogeochemistry: Sinking fractionation of organic carbon in a Swedish fjord, Limnol. Oceanogr., 50, 658-671, doi:10.4319/1o.2005.50.2.0658.
Wheatcroft, R. A., M. A. Goni, J. A. Hatten, G. B. Pasternack, and J. A. Warrick (2010), The role of effective discharge in the ocean delivery of particulate organic carbon by small, mountainos river systems, Limnol. Oceanogr., 55(1), 161-171, doi:10.4319/lo.2010.55.1.0161.

Wilson, D., H. Hisdal, and D. Lawrence (2010), Has streamflow changed in the Nordic countries?-Recent trends and comparisons to hydrological projections, J. Hydrol., 394, 334-346, doi:10.1016/j.jhydrol.2010.09.010.

Zencak, Z., C. M. Reddy, E. L. Teuten, L. Xu, A. P. McNichol, and Ö. Gustafsson (2007), Evaluation of gas chromatographic isotope fractionation and process contamination by carbon in compound-specific radiocarbon analysis, Anal. Chem., 79, 2042-2049, doi:10.1021/ ac061821a. 